\title{
TRAVELLER'S DIARRHOEA - PREVENTION AND TREATMENT IN THE MOUNTAINS
}

\section{CONSENSUS STATEMENT OF THE MEDICAL COMMISSION OF THE UNION INTERNATIONALE DES ASSOCIATIONS D'ALPINISME (UIAA MEDCOM)}

\author{
Thomas Küpper ${ }^{1,2}$, Volker Schoffl' ${ }^{2,3,4}$, Jim S. Milledge ${ }^{2,5}$ \\ ${ }^{1}$ Institute of Occupational and Social Medicine RWTH Aachen Technical University, Aachen, Germany \\ ${ }^{2}$ Medical Commission of the Union Internationale des Associations d'Alpinisme (UIAA MedCom) \\ ${ }^{3}$ Dept. of Sportorthopedics, Klinikum Bamberg, Germany \\ ${ }^{4}$ Dept. of Trauma Surgery, Friedrich Alexander University Erlangen-Nuremberg, Germany \\ ${ }^{5}$ University College London, Great Britain, UK
}

\begin{abstract}
Traveller's diarrhoea may impair mountaineers significantly more than other travellers as they are often dehydrated, water is limited and they have to manage themselves in a harsh environment where any decrease of performance may be dangerous, e.g. onset of acute mountain sickness (AMS) or decreased fitness - both may be induced by diarrhoea. Therefore the problem should be managed more aggressively than in normal travellers.

This guideline of the Medical Commission of the International Climbing and Mountaineering Federation (Union Internationale des Associations d'Alpinisme, UIAA) is designed to be used by mountaineers worldwide. It is a compromise between detailed and differentiated ("tactical") treatment and the principle "keep it simple".
\end{abstract}

Key words: diarrhoea, altitude, mountaineering, dehydration

\section{Introduction}

Traveller's diarrhoea is one of the most important medical problems for trekkers and expedition mountaineering [1]. The syndrome occurs in $20-70 \%$ of travellers to less developed regions [2-4]. This results often in significant impairment of activities with nearly $40 \%$ of victims changing their itinerary $[1,5]$.

By increasing viscosity of the blood and thereby hampered peripheral flow, a fluid loss of $2 \%$ of total body weight causes a significant loss of performance (about 20\%) [6,7]. This loss of performance is comparable to an additional ascent of $1,500 \mathrm{~m}$. [8-10]. Reduced fluid intake is correlated with incidence and degree of acute mountain sickness (survey in $[11,12]$ ), as well as loss of fluid. For example, there are several cases where acclimatized mountaineers developed acute mountain sickness (AMS) due to diarrhoea induced dehydration instead of further ascent $[11,13]$, Dehydration has an additional performance decreasing effect in hot environments. If the mountaineer is climbing in a hot environment, any percent loss of body weight by dehydration causes an increase of the core temperature of 0.1 to $0.4^{\circ} \mathrm{C}[14]$. In consequence, this will result in an increased risk of heat related diseases.

Although the detail of the data are still in discussion there is no question that the loss of body water and electrolytes impairs not only the physical and mental capacity significantly and increases the risk of AMS, there is also an increased risk of thrombosis / thromboembolism, frostbite and other altitude or cold related health risks. Therefore it is a "must" for any mountaineer to avoid traveller's diarrhoea as much as possible and to treat symptoms consequently.

In contrast to the "normal" travellers who experience diarrhoea at sea level, the consequences of significant diarrhoea can cause an additional increased risk in a high altitude environment, therefore treatment should be started earlier and more "aggressively" than it would be the case for "normal" traveller's visiting resorts or national parks at low altitude. This consensus paper focuses the risk of infection by food, differentiates the severity of the disease and gives recommendations how to treat it. Water hygiene and disinfection is excluded here as it was published elsewhere as an independent recommendation $[15,16]$. The UIAA Medical Commission recommendations are based on an extensive literature review which included international databases such as Medline as well as standard handbooks on travel medicine and altitude medicine.

\section{Germs that induce traveller's diarrhoea}

There are many species which can induce diarrhoea and these species fall into at least four different 
categories: viruses, bacteria, protozoa, and helminths. Therefore there is no "one-and-only prophylaxis" for traveller's diarrhoea. While there are vaccinations against some of them (e.g. hepatitis A, polio, salmonella typhi), for most of them different techniques of personal and group hygiene present the only chance to minimize the risk. But even in the best setting more than $75 \%$ of the visitors make significant mistakes in (food) hygiene [17-19],

\section{Risk determining factors}

Several factors are important for the individual risk: age $<30 y$., the region visited (e.g. traveller's diarrhoea in the Alps ca. 4\%, in Nepal up to 80\%), rainy season, duration of sojourn, type of travelling ("adventure travel", mountaineering), reduced gastric acid ( $\mathrm{H}_{2}$-Blockers, acid absorbing drugs etc.), reduced immunocompetence, diabetes or previous stay in a developing country for $>6$ months $[2-5,17-19]$. A checklist which classifies the risk of food is given in table 1. But it should be mentioned here that the individual risk for traveller's diarrhoea is highly variable. Some observations indicate, that a permanent stay in a developing country for more than 6 months decreases the chance of getting diarrhoea, possibly because the bowel gets "conditioned".

Persons who have one or more of these risk factors should get individual advice by a physician experienced in travel medicine. Special attention and training should be given to any person - traveller or local staff - who handles food. Hygiene of hands (washing before food handling!), cleaning surfaces or equipment (dishes, spoons, knives...) which get in contact with food is essential. It is a good idea to separate any meat products away from vegetables, fruits, or eggs. Keep separate any food/s which may be contaminated with pathologic microorganisms.

\section{Prevention of traveller's diarrhoea}

Maintain strict hygiene with respect to water management and managing any human waste (see also [15, 16]. Maintain strict personal hygiene, especially wash your hands before you handle any kind of food, water or beverage. Drink only beverages from safe water sources (cooked or treated for disinfection $[15,16]$ ) or safe industrial beverages. Avoid non-cooked milk or milk products and salad, meat must be well done. Eat peeled fruits only, but take care that they are peeled by yourself, otherwise the problem may not be solved if the person who peeled the fruit had contaminated hands. Be careful: Some fruits are dangerous, even if they are peeled! Melons, for example, are sold by weight. If you inject water at the stipe or at the dried rest of the flower, the fruit will be heavier and therefore more expensive, but if the injected water was unsafe, the water and sugar containing fruit is an optimal incubator for bacteria, especially if the fruit is stored in the sun. Do not eat cold sauces or products made from fresh eggs without cooking.

Clean dishes, cutlery, pans and pots always with safe water, at least for the final cleaning. If safe water is a problem, unsafe water can be used for basic cleaning. The member who is ill with diarrhoea may not be able to climb. Do not ask him/her to prepare food

Table 1. Risk checklist for travellers

\begin{tabular}{|c|c|c|c|}
\hline & Safe & Relatively safe & Unsafe or less Safe \\
\hline \multirow[t]{3}{*}{ Food } & $\begin{array}{l}\text { Hot, well done (barbequed, } \\
\text { cooked, or roasted) }\end{array}$ & Dried products & Salad \\
\hline & $\begin{array}{l}\text { Industrial processed and } \\
\text { packed }\end{array}$ & $\begin{array}{l}\text { Hyperosmolar food (e.g. } \\
\text { jam, syrup) }\end{array}$ & Sauces and "salsas" \\
\hline & $\begin{array}{l}\text { Cooked vegetables and fru- } \\
\text { its which need to be peeled }\end{array}$ & Washed vegetables or fruits & $\begin{array}{l}\text { Uncooked seafood or undercooked or } \\
\text { cold meat (e.g. salami), unpeeled fruits, } \\
\text { non-pasteurized milk products, cold } \\
\text { desserts, ice-cream }\end{array}$ \\
\hline \multirow[t]{4}{*}{ Beverages } & Carbonated soft drinks & Fresh citrus juice & $\begin{array}{l}\text { Water from springs or wells (not disin- } \\
\text { fected) }\end{array}$ \\
\hline & $\begin{array}{l}\text { Industrial produced carbo- } \\
\text { nated mineral water }\end{array}$ & $\begin{array}{l}\text { Bottled water (locally pro- } \\
\text { duced) }\end{array}$ & Tap water, rivers \\
\hline & Boiled water, coffee, or tea & $\begin{array}{l}\text { Ice, industrial processed } \\
\text { and packed }\end{array}$ & Ice-cubes or crushed ice for drinks \\
\hline & Disinfected water & & Non-pasteurized or unsterilized milk \\
\hline Setting & $\begin{array}{l}\text { Well-known restaurants of } \\
\text { international standard }\end{array}$ & $\begin{array}{l}\text { Private homes, restaurants } \\
\text { recommended as "high } \\
\text { class" in international gu- } \\
\text { idebooks }\end{array}$ & $\begin{array}{l}\text { Street vendors, public markets, restau- } \\
\text { rants recommended in guidebooks as } \\
\text { "cheap" }\end{array}$ \\
\hline
\end{tabular}


Table 2. Ingredients to prepare 1 litre of oral rehydration solution (ORS) using sterilised water. Dosage (after each diarrhoeic defecation): "standard glass (125 ml) for preschool children (2-5 yrs.), childs (6-12yrs.) 1 glass, adolescents and adults 2 glasses

\begin{tabular}{|l|c|c|}
\hline Ingredient & WHO recommendation & Home made mixture \\
\hline Table salt & $3.5 \mathrm{gr}$. & 1 teaspoon of table salt \\
\hline Sodium bicarbonate & $2.5 \mathrm{gr}$. & $1 / 2$ teaspoon of baking powder \\
\hline Potassium chloride & $1.5 \mathrm{gr}$. & Eat 1 banana or dried apricots \\
\hline Glucose & $20.0 \mathrm{gr}$. & 4 teaspoons \\
\hline or normal sugar & $40.0 \mathrm{gr}$. & 8 teaspoons \\
\hline
\end{tabular}

or work in the kitchen so that food is ready on return for those who continue to climb!

Note: The slogan "peel it, boil it, cook it, or forget it" does not guarantee safe food! Because some germs produce heat-resistant toxins, the quality of the food which will be cooked is very important, independent from the kind of processing. Ensure the quality of any food eaten (processed or not) is of a good quality. Or remember a five star hotel can have a zero start kitchen if there are no hand washing facilities for the staff. Ensure that any person who is involved in the handling or preparation of food regularly washes his/her hands before touching food or kitchen equipment and before eating! There will be many situations where safe water is sparse. Here hygienic towels with disinfectant may be used for hands, cutlers, and dishes (after a rough cleaning with unsafe water).

\section{Symptoms of traveller's diarrhoea}

In most cases symptoms occur on about the third day after arrival (incubation period $6 \mathrm{hrs}$ to some days). The duration of symptoms is usually $3-4$ days (untreated), but in $10 \%$ of cases last for more than 1 week and about $1 \%$ develop chronic diarrhoea $(>3$ weeks).

Gastroenteritis or enterocolitis is the course of the disease for most patients. This includes watery, in some cases mucous diarrhoea, diffuse abdominal pain, vomiting and body temperature up to $38.5^{\circ} \mathrm{C}$. Most cases are self-limiting within 3-5 days. About $10 \%$ of the patients develop dysentery with puss or blood in the stool, tenesmus, and fever up to more than $40^{\circ} \mathrm{C}$.

\section{Therapy of traveller's diarrhoea}

The most important therapy of diarrhoea is rehydration. Start early to limit the consequences! Adults should drink about $1 / 41$ per defecation (= 2 glasses), children 1 glass. Except in case of minimal symptoms use electrolytes for rehydration (Oral Rehydration Solution - ORS, table 2). Note: some commercially available products are for adults only! If used for children take care to give the correct dosage. Note: No further ascent until the symptoms have been cured and the patient is completely rehydrated! For the use of drugs the severity of symptoms should be considered:

Moderate symptoms should be treated with rehydration as mentioned above, plus loperamide ( $1^{\text {st }}$ dosage $4 \mathrm{mg}$ ( 2 capsules), then 1 capsule for every liquid defecation, but not more than $12 \mathrm{mg} /$ day or longer than for 48 hours) Note: the capsules are for patients older than 8 years only (special dosage for 2-8 years are available).

Severe symptoms should be treated like moderate symptoms plus chinolon (e.g. ofloxacine, $400 \mathrm{mg} / \mathrm{d}$, or ciprofloxacine, $500 \mathrm{mg} / \mathrm{d}$ ). Note: Campylobacter is a common cause of traveller's diarrhoea in Nepal. Here (and in other regions of south-east Asia) azithromycin is recommended $(500 \mathrm{mg} 1 \mathrm{x} / \mathrm{d}$ for 3 days). If azithromycin should have no significant effect, consider non-bacterial germs (use metronidazole as mentioned above) or switch to levofloxacin (500 $\mathrm{mg} /$ day for 5 days).

Note: Burbing with disgusting taste, stinking flatulence, abdominal pain, bloating and nausea may indicate Giardia infection (relatively common especially in India and Nepal, but also in the Rocky Mountains). Therapeutic options [4]: metronidazole 750-1000 mg/d for 5 days ( $3 \times 250 \mathrm{mg}$ ) or tinnidazole $2 \mathrm{~g}$ single dose for adults, for children $\geq 6 \mathrm{y} .15-30 \mathrm{mg} / \mathrm{kg} /$ day in $2-3$ dosages for 7 days. There is no single drug available which is able to treat all patients with Giardia effectively. If symptoms persist try another one.

Contact a physician in case of the following situations:

Fever $>39^{\circ} \mathrm{C}$

Vomiting, which doesn't stop for $>2 \mathrm{~d}$

Dysentery (see above)

Symptoms $>5$ days

Pregnancy

Small child ( $<6-8$ y, or so)

Elderly person ( $>75 \mathrm{y}$, or so)

Severe dehydration / cardiocirculatory symptoms

\section{References}

1. Ostrosky-Zeichner L, Ericsson CD. Travelers' diarrhea. In: Zuckerman JN, Editor. Principles and practice of travel medicine, New York: John Wiley \& Sons Ltd, 2001, p. 153-62

2. DuPont HL, Ericsson CD. Prevention and treatment of travellers' diarrhea. N Engl J Med 1993; 328: 1821-7. 
3. Petola H, Gorbach SL. Travellers' diarrhea: epidemiologyand clinical aspects. In: DuPont HL, Steffen R, Editors. Textbook of travel medicine and health, Hamilton, Ontario $(\mathrm{CN})$ : B.C. Decker Inc., 1997, p. 78-86.

4. Adachi JA, Backer HD, DuPont HL. Infectious diarrhea from wilderness and foreign travel. In: Auerbach PS, Editor. Wilderness Medicine, St. Louis (Missouri, USA): Mosby Inc., 2007, p. 1418-44.

5. Ericsson CD, DuPont HL. Travellers' diarrhea: approaches to prevention and treatment. Clin Infect Dis 1993; 16: 616-24.

6. Hollmann W, Hettinger T. Sportmedizin, Grundlagen für Arbeit, Training und Präventivmedizin. Stuttgart: Schattauer, 2000, p. 342-3.

7. Scott D, Rycroft JA, Aspen J, et al. The effects of drinking tea at high altitude on hydration status and mood. Eur J Appl Physiol 2004; 91: 493-8.

8. Kupper T, Ebel K, Gieseler U. Modern Mountain and Altitude Medicine. Gentner Verlag: Stuttgart, 2010.

9. West JB. Limiting factors for exercise at extreme altitudes. Clin Physiol 1990; 10(3): 265-72.

10. Buskirk ER, Kollias J, Akers RF, et al. Maximal performance at altitude and on return from altitude in conditioned runners. J Appl Physiol 1967; 23: 259-67.

11. Nerin MA, Palop J, Montano JA, et al. Acute Mountain Sickness: Influence of fluid intake. Wilderness Environ Med 2006; 17(4): 215-20.

12. Cumbo TA, Basnyat B, Graham J, et al. Acute mountain sickness, dehydration, and bicarbonate clearance: preliminary field data from the Nepal Himalaya. Aviat Space Environ Med 2002; 73(9): 898-901.

13. Murdoch DR. Symptoms of infection and altitude illness among hikers in the Mount Everest region of Nepal. Aviat Space Environ Med 1995; 66(2): 148-51.

14. Moeller D. Drinking water and liquid waste. Environmental health, Boston: Harward University Press, 1997.
15. Küpper T, Schoffl V, Milledge J. Water Purification in the Mountains - State of the Art. Travel Med Infect Dis 2009; 7(1): 7-14.

16. Kupper T, Schoffl V, Milledge J. Consensus Statement of the UIAA Medical Commission No.6: Water Disinfection in the Mountains. 2008. Available from: www.theuiaa.org/medical_advice.html

17. Steffen R. Epidemiology of traveler's diarrhea. Clin Infect Dis 2005; 41(Suppl) 8: S536-40.

18. Steffen R. Prophylaxe bei Reisenden in Entwicklungsländer. Flug-Reisemed 2003; 10(1): 12.

19. Steffen R. Gesundheitsgefährdung bei Aufenthalt in Entwicklungsländern. Flug Reisemed 2001; 8(4): 10.

Received: July 25, 2010

Accepted: August 25, 2010

Published: August 31, 2010

Address for correspondence:

Thomas Küpper, Assoc. Prof., MD, PhD

Institute of Occupational and Social Medicine

RWTH Aachen Technical University

Pauwelstr. 30

D-52074 Aachen

tkuepper@ukaachen.de

Members of UIAA MedCom

C. Angelini (Italy), B. Basnyat (Nepal), J. Bogg (Sweden), A.R. Chioconi (Argentina), S. Ferrandis (Spain), U. Gieseler (Germany), U. Hefti (Switzerland), D. Hillebrandt (U.K.), J. Holmgren (Sweden), M. Horii (Japan), D. Jean (France), A. Koukoutsi (Greece), J. Kubalova (Czech Republic), T. Küpper (Germany), H. Meijer (Netherlands), J. Milledge (U.K.), A. Morrison (U.K.), H. Mosaedian (Iran), S. Omori (Japan), I. Rotman (Czech Republic), V. Schöffl (Germany), J. Shahbazi (Iran), J. Windsor (U.K.)

\begin{tabular}{lll}
\hline Authors' contribution & B - Data Collection & D - Data Interpretation \\
A - Study Design & C - Statistical Analysis & E - Manuscript Preparation
\end{tabular}

